\title{
On the origin of inflected "non-finite" forms: the infinitive vs the supine
}

\author{
Adina Dragomirescu ${ }^{1,2 *}$, Alexandru Nicolae ${ }^{1,2 *}$ \\ 1 "Iorgu Iordan - Al. Rosetti" Institute of Linguistics, 13 Calea 13 Septembrie, 050711 Bucharest, Romania \\ ${ }^{2}$ Faculty of Letters, University of Bucharest, 5-7 Edgar Quinet St., 010017 Bucharest, Romania
}

\section{Article info}

History:

Received June 1, 2016

Accepted June 11, 2016

Published August 1, 2016

Key words:

inflected infinitive

supine

diachronic change

structure enrichment

\begin{abstract}
This paper deals with two verbal forms which, despite being traditionally labelled as "non-finite", display inflection/agreement. We will focus on the behaviour and origin of the inflected infinitive attested in Romance and in languages from other families, against which we analyse the novel inflected supine found in the north-eastern area where Romanian is spoken (comprising the Republic of Moldova, Ukraine and the north-eastern part of the Romanian province of Moldova). The goal of the paper is to identify the common paths of diachronic change of these verbal forms and to put forward a formal account of the observed diachronic changes. From a diachronic perspective, our analysis shows that the functional structure of non-finite forms may become more enriched, a conclusion that is at odds with traditional findings, which generally argue for simplification, not enrichment of functional structure. At the same time, the proposed analysis also offers some insights into the diachrony of the supine marker de.
\end{abstract}

\section{Introduction}

In this paper we present the most significant linguistic data related to the inflected infinitive found in Romance and in languages from other families, focusing our attention on the origin and evolution of these forms as they are presented in the literature. We then turn to a series of recent special usages of the Romanian supine in the Moldavian variety employed in The Republic of Moldova, Ukraine and northeastern Romania ${ }^{1}$, which bring the Romanian supine closer to the Romance inflected infinitive. Finally, we put forward a scenario which accounts both for the innovations in the morphosyntax of the Romanian supine (the enrichment of its functional structure) and for the diachronic recategorization of the supine marker $d e$.

On the basis of the data presented below, our goal is to answer the following questions:

(i) to what degree is the inclusion of these inflected forms in the 'non-finite' category justified?;

(ii) what is the relevance of the origin and evolution of these forms for their morphosyntactic behaviour?;

(iii) what are the definitional features of the infinitive (and of non-finite forms in general), including control properties, ability to accept a subject and morphology?;

(iv) do the diachronic changes that affect these forms also lead to processes of grammaticalization?

We have chosen to compare the Romanian supine with the inflected infinitive from other languages because, of the Romanian non-finite forms, only the supine appears to favour the attachment of inflectional markers, while the infinitive remains non-inflected for person and number. The analysis of the

\footnotetext{
*Email addresses: adina_drag@yahoo.com,nicolae_bibi@yahoo.com.

${ }^{1}$ In this paper, we will mostly use data excerpted from the internet; however, we have identified inflected supines in the personal corpus put together by Valentina Cojocaru and in the corpus included in Bochmann's book (Klaus Bochmann (Hrsg.) (2004). Gesprochenes Rumänisch in der Ukraine. Soziolinguistiche Verhältnisse and linguistische Strukturen, Leipziger Universitätsverlag, Leipzig).
} 
Romanian supine will be shown to contribute to a better understanding of the category of 'finiteness', a concept insufficiently understood in current syntactic theorizing, and of the diachrony of this category (see Ledgeway, 2007; Vincent, 1998).

\section{The inflected infinitive}

Before delving into the analysis of the inflected infinitive data, it is necessary to make a terminological clarification (following Ledgeway, 1998): we distinguish between the 'personal' infinitive particular to many languages including Romanian (see Mensching, 2000), a form which may take its own lexical subject in the nominative (1), and the 'inflected'/'conjugated' infinitive limited to a more limited number of languages and which displays person and number agreement with the subject (2).

In what follows, we exclusively deal with the 'inflected'/'conjugated' infinitive, which is attested in languages distinct from a genealogical and typological point of view: Portuguese, Galician, Sardinian, Southern Italian Dialects from South Calabria, Old Neapolitan, Old Leonese (of the Romance varieties), Hungarian, Welsh, West Greenlandic, Evenki (a Manchu-Tungusic language) and, probably, Greek.

Miller (2003) formulated the hypothesis that the emergence of the inflected infinitive is determined by the presence of the lexical subject (allowed by the inflected infinitive only in very restricted contexts Ledgeway, 2000, 2007), which has inherent subject agreement features (i.e., phi-features).

(1) Înainte de a veni vara $a_{\text {subject, }}$

before of to come.INF summer.DEF.NOM

am muncit mult. (Romanian)

AUX.PERF.1PL worked a.lot

'Before the summer came, we worked a lot'

(2) 'sing'

\begin{tabular}{|c|c|c|c|c|c|c|}
\hline & $\begin{array}{l}\text { European } \\
\text { Portuguese }\end{array}$ & $\begin{array}{l}\text { Brasilian } \\
\text { Portuguese }\end{array}$ & Galician & $\begin{array}{l}\text { Old } \\
\text { Leonese }\end{array}$ & Sardinian & $\begin{array}{l}\text { Old } \\
\text { Neapolitan }\end{array}$ \\
\hline $1 \mathrm{SG}$ & cantar- $\emptyset$ & cantar- $\emptyset$ & cantar- $\varnothing$ & cantar- $\emptyset$ & kantáre-po & cantare- $\varnothing$ \\
\hline $2 s G$ & cantar-es & & cantar-es & cantar-es & kantáre-s & cantare- $\emptyset$ \\
\hline $3 S G$ & cantar- $\varnothing$ & cantar- $\varnothing$ & cantar- $\varnothing$ & cantar- $\varnothing$ & kantáre-t & cantare- $\varnothing$ \\
\hline $1 \mathrm{PL}$ & cantar-mos & cantar-mos & cantar-mos & cantar-mos & kantáre-mus & cantare-mo \\
\hline $2 \mathrm{PL}$ & cantar-des & & cantar-des & cantar-des & kantáre-dzis & cantare-vo/ve \\
\hline $3 P L$ & cantar-em & cantar-em & cantar-en & cantar-en & kantáre-n & $\begin{array}{l}\text { cantare-no } \\
\text { Groothuis, 2015) }\end{array}$ \\
\hline
\end{tabular}

\subsection{The Romance languages}

\subsubsection{Portuguese}

Of the Romance languages, the Portuguese inflected infinitive (3) has been subject to most attention in the literature (Raposo, 1987; Madeira, 1994; Pires, 2002; Miller, 2003; Martins, 2006; Bossaglia, 2013; Carvalho, 2015 i.a.). As is obvious from (3b), the subject of the inflected infinitive may be overtly realised (see also Rouveret, 1980).

(3) a. Depois de chegarem, fugimos after of arrive.INF.3PL fled.1PL

'After they arrived, we fled'

(Willis, 1971, p. 338, apud Bentley, 2014, p. 96) 

b. despois de eles chegarem viram as ruínas after of they.NOM arrive.INF.3PL saw.3PL the ruins 'after they arrived, they saw the ruins' (Willis, 1971, p. 338, apud Ledgeway, 1998, p. 7)

Groothuis (2015) shows that the structure in which the European Portuguese inflected infinitive is employed is biclausal, on the basis of two diagnostics: the matrix verb and the embedded infinitive may have distinct lexical subjects (4a), and both predicates may be simultaneously modified by the same adverbial (4b):

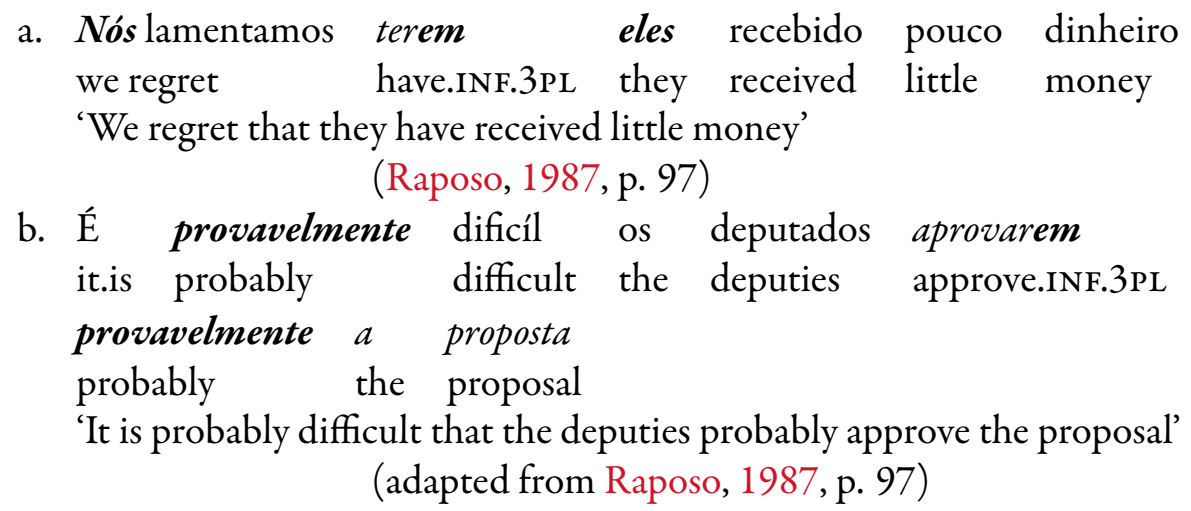

There are significant differences between Old and Modern Portuguese with respect to the distribution of the inflected infinitive. First, while in Modern Portuguese this form is available only in embedded clauses (Raposo, 1987, p. 86), in Old Portuguese it could appear in both main and embedded clauses (Martins, 2006, p. 342). Second, there are significant differences between the two stages of Portuguese with respect to the infinitive selected by causative verbs and direct perception verbs: while the canonical infinitive is selected by these classes of verbs in both stages of Portuguese ( $5 \mathrm{a}$ ), the inflected infinitive is not attested in Old Portuguese in these contexts, but it is perfectly grammatical in present-day Portuguese ( $5 \mathrm{~b}$ ) (see also Sheehan, 2015, where a series of less categorical findings are presented); thus, examples like (5b) are not attested in pre- $15^{\text {th }} \mathrm{c}$. Portuguese, but are perfectly grammatical starting with the $15^{\text {th }} \mathrm{c}$. (Martins, 2006).
a. Mandei/ Vi os polícias prender
o ladrão
sent/ saw the corps arrest.INF
the thief
b. Mandei/ Vi os polícias prenderem
o ladrão
sent/ saw the corps arrest.INF.3PL the thief
'I made/I saw the policemen detain the thief'

(Martins, 2006, p. 327)

It appears that this distribution correlates with other features of the canonical infinitive in control or raising configurations. Thus, while in Old Portuguese verbal negation did not precede the infinitive in these structures, but rather occurred on the main predicate, in Modern Portuguese both the embedded infinitive and the selecting verb may be independently negated. Thus, while example (6a) is possible in both phases of Portuguese, (6b) is available only in Modern Portuguese. A similar characterizes pronominal clitics which, with few exceptions, undergo clitic climbing on the higher predicate in Old Portuguese; by contrast, in Modern Portuguese they either remain in situ and cliticize on the infinitive, or undergo clitic climbing to the matrix predicate. Thus, $(7 \mathrm{a})$ is attested in both stages of Portuguese, while $(7 \mathrm{~b})$ is wellformed only in Modern Portuguese. This state of affairs is indicative of the fact that the syntactic structure of the infinitive was reduced in older stages of Portuguese: the structure [selecting verb + infinitive] seems to display the typical behaviour of restructuring (Rizzi, 1978) in Old Portuguese. 
(6) a. O medico não o mandou beber vinho the doctor not CL.ACC.M.3sG sent drink.INF wine

b. O medico mandou-o não beber vinho the doctor sent=CL.ACC.M.3sG not drink.INF wine 'The doctor didn't send him to drink wine'

(Martins, 2006, p. 328)

(7) a. Mandou-lho entregar sent.3SG=CL.DAT.M.SG=it.ACC give.INF

b. Mandou entregar-lho sent.3sG give.INF=CL.DAT.M. $3 \mathrm{sG}=$ it.. $\mathrm{ACC}$ 'He/she sent to give it to him'

(Martins, 2006, p. 328)

Martins (2006) shows that these phenomena are indicative of a syntactic change, from a more reduced to a more extended functional structure, in the history of the Portuguese infinitive. For the analysis of the Romanian dialectal supine, we will keep in mind the idea that the functional structure of non-finite forms undergoes a diachronic process of enrichment.

\subsubsection{Sardinian}

Relevant data on the Sardinian inflected infinitive (8) are given especially by Jones (1992, 1993, 2003) and Miller (2003). In Sardinian, the inflected infinitive is devoid of temporal autonomy and does not have an inflectionally specific profile, being syncretic with a finite form, the imperfect subjunctive. This syncretism results from the common origin of these forms, the Latin imperfect subjunctive (Jones, 1993, p. 278).

(8) 'sing'

\begin{tabular}{l|ll} 
& Singular & Plural \\
\hline 1 & cantárepo & cantáremus \\
2 & cantares & cantáredzis \\
3 & cantaret & cantaren
\end{tabular}

(Jones, 1992, p. 298)

The difference between the two verbal forms is apparently given by the type of complementizer which introduces them and by the position of the subject. In $(9 \mathrm{a})$ the imperfect subjunctive appears in clause headed by the finite complementizer $k i$, and the subject is preverbal, while in (9b) the inflected infinitive is headed by $a$, and the subject is postverbal (Jones, 1993, p. 279). Word order differences of this type usually correlate with different $\mathrm{V}$-raising options in the functional structure of the clause ( V-to-I / V-toC), a further potential difference between these two forms.

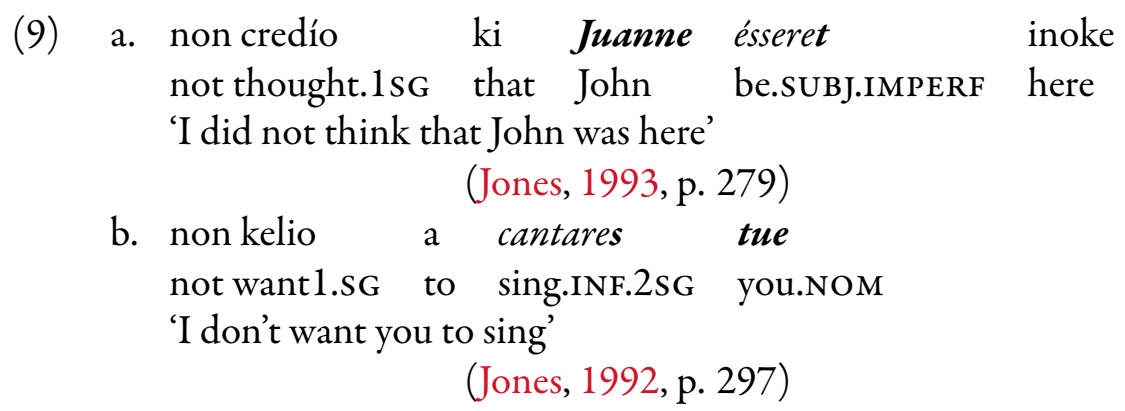

Furthermore, the distribution of these two forms is not identical. The inflected infinitive is employed when its subject has independent reference (10a), but is usually excluded in obligatory control configurations (10b). 

a. devo
accabbare
custu travallu
prima
de ghiraret
sumere must.1sG finish.INF this work before 'I must finish this job before the boss returns'

$$
\text { (Jones, 1993, p. 279) }
$$

b. ?provo a travallarepo

try.1SG to work.INF.1sG

'I am trying to work'

(Jones, 1993, p. 280)

\subsubsection{Old Neapolitan}

The Old Neapolitan inflected infinitive (analysed especially by Ledgeway, 2007, 2009, Vincent, 1998 and Miller, 2003) appears in two types of contexts (Ledgeway, 2007, p. 338-339). In non-obligatory control configurations, the inflected infinitive is also a personal infinitive, i.e. it can take its own subject (11a-b). In obligatory control configurations, the subject of the infinitive is obligatorily shared with the selecting predicate, and the infinitive is devoid of temporal independence (11c). In both distributional contexts, it is preceded by $a$ or $d e$, which have been analysed as complementizers. The inflected infinitive has specific forms only in the plural; its singular forms are syncretic with the canonical infinitive-see the Table in (2) above. According to Ledgeway (2007, p. 340-341), the paradigmatic pressure of the singular, which contained only forms syncretic with the canonical infinitive, determined the loss of the plural inflection of the infinitive.

$$
\begin{aligned}
& \text { a. ave plazuto a li nuostri Diey de nuy esseremo in questa parte } \\
& \text { has pleased DAT the our Gods of us be.INF.1PL in these parts } \\
& \text { 'it pleased our Gods for us to be in these parts' } \\
& \text { (Ledgeway, 2009, p. 600) } \\
& \text { b. per nuy averemo ordene } \\
& \text { for we have.INF.1PL orders } \\
& \text { 'so that we may receive orders' }
\end{aligned}
$$$$
\text { (Ledgeway, 2009, p. 922) }
$$$$
\text { c. se nui avertevamo de le andarimo appriesso }
$$$$
\text { if we considered of CL.ACC.3PL=go.INF.1PL after }
$$$$
\text { non ne scapava nissciu(n)o }
$$$$
\text { not CL.DAT.1PL=escaped not.one }
$$$$
\text { 'if we had intended to go after them, not one of them would have got away' }
$$$$
\text { (Ledgeway, 2007, p. 338) }
$$

\subsubsection{Southern Italian Dialects}

Although traditional scholarship does not record the existence of the inflected infinitive in southern Calabrian varieties, Ledgeway (1998) has shown that the clauses headed by mu/ma/mi (< Lat. MODO) are infinitival (see also Miller, 2003, Ledgeway, 2007), in opposition to those headed by ca-/chi-, which are finite. The following arguments have been invoked for granting infinitival status to the modern reflexes of Lat. MODo (Ledgeway, 1998, 2007; see also Taylor, 2016 for a discussion of MODO in Nicoterese):

(i) the only possible word order is subject > MODO (12a), which indicates that MODO is not a complementizer, as complementizers are higher than the subject in the clausal hierarchy;

(ii) MODO can co-occur with another complementizer, namely $c a$, especially in hortative sentences (in (12b), chimmu < ca +mu);

(iii) clauses headed by MODO are devoid of temporal independence; their tense is anaphoric, i.e. fully determined by the tense specification of the higher selecting predicate. 
(12) a. vostra mama mu vi vidi Cavaleri your mother to CL.2PL see.INF.3SG gentlemen 'for your mother to see you, gentlemen'

(Zungri, Fiori Selvatici, 1894, p. 125, apud Ledgeway, 1998, p. 24)

b. vi promettu, si non vi pagu, chimmu moru schjettu! CL.2PL promise.1sg if not CL.2PL play.1sg COMP-INF die.1sG bachelor 'I promise you, if I don't pay you, (it is my whish) that I may die a bachelor'

(Siderno, Filocamo, 1984, p. 41, apud Ledgeway, 1998, p. 30)

Thus, southern Calabrian MODo is an infinitival marker, just like $a$ and $d e$ in other Romance varieties, and the verbal form it introduces is similar to the inflected infinitive.

\subsection{Non-Romance languages}

The data on the inflected infinitive in non-Romance idioms are rather scant, hence probably incomplete. Forms considered as matching the Romance inflected infinitive have been recorded in Standard Greek and Romeyka (/Pontic Greek, a dialect of Greek spoken in north-eastern Turkey), Hungarian, Evenki, and Welsh.

\subsubsection{Greek}

With respect to Standard Modern Greek, Miller (2003) considers that the verbal form inflected for person and number agreement with the subject and preceded by $n a$ is quasi-infinitival, on a par with what was noted above for southern Calabrian. However, most scholars have analysed the na-structures as subjunctives which have diachronically replaced the infinitive. Miller (2003) supports his proposal with the following arguments:

(i) these structures appear in obligatory control configurations (13);

(ii) weak cross-over effects indicate that the subject of the na-forms is PRO (14);

(iii) the na-structure may be dominated by a determiner/article (14).
a. i Maria
prospathi-s-e na diavas-i
the Maria.NOM.SG try.PST.3sg to read.3sG
'Mary tried to read'
b. ? i Maria prospathise na divas-un
the Maria.NOM.SG try.PST.3SG to read.3PL
'Mary tried for them to read'

$$
\text { (Terzi, 1997, p. 338) }
$$

(14) pion $_{\mathrm{i}}$ nevriaz-i to $\mathrm{PRO}_{\mathrm{i}}$ na plen-i to aftokinito (tu) $\mathrm{t}_{\mathrm{i}}$ whom upset.3sG the to wash.3sg the car his 'who does washing his/the car upset'

$$
\text { (Terzi, 1997, p. 346) }
$$

Romeyka presents two features which distinguish its infinitival system from that of Standard Modern Greek (Sitaridou, 2014): (i) the canonical and the personal infinitive (i.e. the infinitive that may take its own subject) have been preserved, and (ii) there emerged a novel form, the inflected infinitive (15).

(15) 'say'

\begin{tabular}{l|ll} 
& Singular & Plural \\
\hline 1 & ipina & ipiname \\
2 & ipines & ipinete \\
3 & ipine & ipinane
\end{tabular}

Sitaridou (2014) accounts for the emergence of the Romeyka inflected infinitive through the influence of the Caucasian Sprachbund on this Greek dialect. 


\subsubsection{Hungarian}

As shown by Miller (2003), Hungarian possesses a canonical infinitive, whose ending is -ni, and an inflected infinitive, in the structure of which the morpheme $-n i$ is followed by person and number agreement markers. The inflected infinitive has been attested since Old Hungarian. While the canonical infinitive has a controlled PRO subject (16a), the subject of the inflected infinitive is either overtly realised or null (i.e. pro) (16b):
a. sikerült [PRO kinyit-ni az ajtó-t $]$ succeeded open.INF the door.ACC 'opening the door succeeded'
b. sikerült [pro kinyit-n-om az ajtó-t] succeeded open.INF.1sG the door.ACC 'I succeeded in opening the door'

(Kiss, 1987, p. 222)

\subsection{The origin of the inflected infinitive}

Miller (2003) identifies two general sources for the inflected infinitive: the purpose subjunctive (in Romance and Balkan languages) and the adjunction of pronominal elements on nominalizations (in Hungarian, West Greenlandic, and Welsh). However, the analysis of a bigger number of languages shows that the sources of the inflected infinitive are more diverse.

\subsubsection{The inflected infinitive originating from other verb forms}

2.3.1.1. At least three hypotheses have been put forward for the origin of the Portuguese inflected infinitive (see Pires, 2002; Miller, 2003; Scida, 2004; Carvalho, 2015):

(i) José Maria Rodrigues (1913) claims that the inflected infinitive directly descends from the Latin imperfect subjunctive, both with respect to its form (17), and with respect to some of its functions; this "subjunctive" remained in use until the $15^{\text {th }}-16^{\text {th }}$ centuries (Ledgeway, 1998, p. 6).

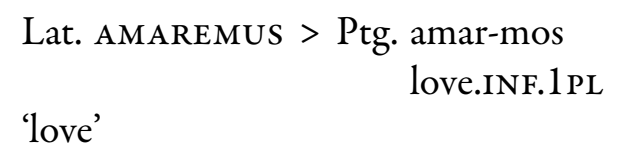

(ii) Theodoro Henrique Maurer (1984) claims that the origin of the inflected infinitive is the personal infinitive; in other words, the inflected infinitive emerged analogically and spontaneously from the personal infinitive with a nominative subject.

(iii) Gamillscheg (1970), also followed by Miller (2003), puts forward a mixed hypothesis, according to which the inflected infinitive resulted from the overlapping between the Latin imperfect subjunctive and the Romance infinitive in specific contexts:
a. Lat. Placuit (nōbis) vende-re pleased.3sg we.DAT sell.INF 'it was agreeable (to us) to sell'
b. VLat. Placuit nobis ut venderemus pleased.3sg we.DAT COMP sell.CONJ.IMPERF.1PL 'it was agreed that we sell'
c. VLat. Placuit venderemus pleased sell.sUBJ.IMPERF.1PL 'It was agreed that we sell'$$
\text { (Roberts, 1953-1957, p. 30-31) }
$$ 


\section{d. Ptg. agradou-nos vendermos \\ pleased.3sG-us sell.INF.1PL \\ 'it pleased us to sell'}

As shown by Miller (2003), the Latin infinitive (18a) and imperfect subjunctive (18b) were functionally equivalent and occurred in free variation in many texts. Since Early Latin, the complementizer $u t$ ('to, in order that/to') was frequently omitted as in (18c) (see Pires, 2002, p. 145). Accordingly, at the basis of the Portuguese inflected infinitive lie structures like (18c), the diachronic change being favoured by the formal resemblance of the Latin and Portuguese canonical active infinitive (Lat. vendere, Ptg. vender) and by other common contexts of occurrence.

2.3.1.2. The source of the Old Neapolitan inflected infinitive is the Latin pluperfect indicative (Loporcaro, 1986; Ledgeway, 1998, p. 6; Martin Maiden, p.c., expresses serious doubts about the accuracy of this hypothesis, arguing that the inflected infinitive is built with the imperfective stem and not with the perfective stem, specific to the pluperfect). Interestingly, in Old Neapolitan all non-finite forms also had inflected variants, albeit not used with the same frequency for all persons (Loporcaro, 1986, p. 173-174).

$$
\operatorname{AMA}(\mathrm{VE}) \mathrm{RAMU}(\mathrm{s})>\text { amàramo 'we had loved' > amare-mo /a'marəmə/ 'love.INF.1 PL' }
$$

2.3.1.3. The origin of the Romeyka inflected infinitive is the canonical infinitive. Sitaridou (2014) puts forward the following scenario depicting this process: the contrafactive form ixa ('I had') plus the infinitive is attested in the medieval period; appearing in strict adjacency to the verb ixa, the infinitive develops analogic inflection, identical to the aorist of ixa (20). Analogy was also favoured by the formal identity between the canonical infinitive and the third person form of the aorist. Subsequently, the inflected infinitive spread as a complement of modal verbs and, due to the fact that Romeyka does not possess complementizers, in other contexts as well (as a complement of volitional, causative and perception verbs).
ipina
had.3SG say.AOR.INF.1sG
a. ixe
'If I had said'
b. ixe ipines
had.3SG say.AOR.INF.2sG
'If you had said'

\subsubsection{The inflected infinitive originating from other classes of words}

2.3.2.1. The Welsh inflected infinitive is the result of the reanalysis of some inflecting prepositions as infinitive agreement markers (21b) (Miller, 2004). Welsh does not have an infinitive form with dedicated inflectional marking, but it does have verbal nouns which are sometimes accompanied by the preposition $i$ ('to', 'for'). The inflected infinitive thus resulted from the merger between the marker $i$, agreement markers and the verbal noun; the entire complex possesses person inflection and the preposition $i$ is reanalysed as an infinitival marker (22).
a. i-daw 'to him'
(Middle Welsh)
b. i-ddo 'to-3sG.M'
(Modern Welsh)
death y dyn [i-ddynt ei gweld $\quad$ hi $]$
came the man to.3PL 3sG.F see.NONFIN her
'the man came so they could see her'

(Tallerman, 1998, p. 119)

2.3.2.2. Finally, the source of the Evenki inflected infinitive (23b) is the marker of nominal possession (23a), which was reanalysed as an agreement marker (Miller, 2003). 
a. Possessed nouns (Nedjalkov, 1995, p. 443; 1997, p. 143)

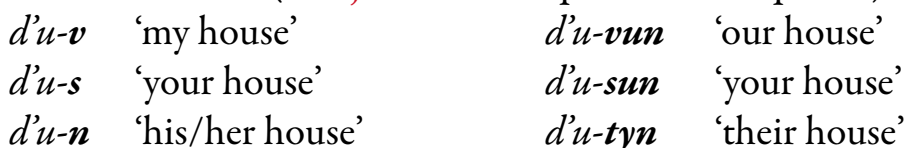

b. Possessed -raki- formation (-raki- = nonfinite suffix; baka- 'find')

$\begin{array}{llll}\text { baka-raki-v } & \text { 'find.I' } & \text { baka-raki-vun } & \text { 'find.we' } \\ \text { baka-raki-s } & \text { 'find.you' } & \text { baka-raki-sun } & \text { 'find.you' } \\ \text { baka-raki-n } & \text { 'find.he/she' } & \text { baka-raki-tyn 'find.they' }\end{array}$

\subsection{Results and problems}

From this brief survey of the inflected infinitive and of its origin, we can draw a few more general observations:

(i) not only the infinitive, but also other non-finite verbal forms have inflected/(subject) agreeing variants; in what follows, we will show that the Romanian supine is such a form with a non-inflected and an inflected variant;

(ii) the source of the Romance inflected infinitive is not the canonical infinitive, but finite forms (the subjunctive, the indicative); the inclusion of these forms in the class of 'infinitives' is due to their distributional (syntactic) rather than inflectional properties;

(iii) of the analysed languages, it appears that the inflected infinitive developed out of the canonical infinitive only in Romeyka and Hungarian (the label 'inflected infinitive' thus seems most appropriate when applied to these languages); we will show that the Romanian inflected supine is an extension of the canonical supine, a fact which draws Romanian closer to Greek varieties or Hungarian rather than to the Romance languages.

Furthermore, in view of the data analysed, one may wonder what a non-finite form is and how an infinitive' can be defined. How is it possible to distinguish an inflected infinitive from a subjunctive in view of the fact that both forms are inflected and may assign nominative case to the subject? It is true that the canonical infinitive is 'non-finite' in the morphological sense (i.e. it does not display number and person agreement with the subject) (see Ledgeway, 2007, p. 336 for the concept of 'morphological finiteness'), but the inflected infinitive is morphologically finite. Potential answers to these questions may be given if we adopt a scalar view on finiteness, as proposed by Ledgeway (1998, p. 8), cf. (24).
a. $[+$ Tense, + Agr $] \rightarrow$ finite clauses (past, present, future)
b. $\quad[+$ Tense, - Agr $] \rightarrow$ personal infinitive (with distinct subject)
c. $[-$ Tense, + Agr $] \rightarrow$ inflected infinitive (with controlled subject)
d. $[-$ Tense, - Agr $] \rightarrow$ canonical infinitive

In this representation, (a) and (d) represent the unmarked options available in many languages, while (b) and (c) represent points of significant cross-linguistic variation (see, for details, Ledgeway, 2000, 2007). In the next section, we will also identify the position of the Romanian supine in this typology.

\section{The Romanian supine: standard vs dialectal}

It is a well-known fact that the Romanian supine is a non-finite form stricto sensu, i.e. it does not display morphological variation and, in general, does not accept a lexical subject, with a few exceptions (Pană Dindelegan, 2011; Dragomirescu, 2011). Its distribution is limited to a few well delimited syntactic contexts (see Pană Dindelegan, 2008, 2013; Dragomirescu, 2013a,b). The Romanian verbal supine has the following relevant syntactic properties: it may take an accusative direct object (25a), and it cannot combine with pronominal clitics (25b), clausal negation (25c), and clitic adverbials (25d). Pronominal clitics, negation and clitic adverbs obligatorily undergo raising to the higher selecting predicate $(25 \mathrm{e})$. 
(25)
$\begin{array}{llll}\text { a. Termină } & \text { de } & \text { scris } & \text { articolul. } \\ \text { finishes } & \mathrm{DE}_{\text {SUP }} & \text { write.SUP } & \text { article.DEF.ACC }\end{array}$
'He/She finishes writing the article'
b. ${ }^{*}$ Termină de il scris.
finishes DE $\mathrm{SE}_{\mathrm{SUP}}$ CL.ACC.M.3SG write.SUP
c. ${ }^{*}$ Termină de $\boldsymbol{n u} / \boldsymbol{n e}$ - scris articolul.
finishes $\mathrm{DE}_{\mathrm{SUP}}$ not write.suP article.DEF.ACC
d. *Termină de mai scris.
finishes $\mathrm{DE}_{\text {SUP }}$ more write.SUP
e. Nûll mai termină de scris.
not CL.ACC.M.3SG more finishes $\mathrm{DE}_{\mathrm{SUP}}$ write.sUP
'He/She hasn't yet finishing writing it'

In some varieties of Romanian spoken in The Republic of Moldova, Ukraine and north-eastern Romania, the supine behaves differently:

(i) it has a wider distribution than in Standard Romanian;

(ii) it may combine with pronominal clitics, clausal negation, and clitic adverbials in certain contexts;

(iii) it may reflect agreement with the subject when it is selected by the verb trebui ('must, have to') or when it appears in tough-constructions.

\subsection{Combination with pronominal clitics}

The ability of the supine to host pronominal clitics in these Romanian varieties has been recorded by Gabinschi (2010) and analysed by Dragomirescu \& Hill (2014) and Dragomirescu (2015). This property manifests itself in the following contexts:

(i) after modal verbs such as a avea ('have') (with a personal paradigm), a trebui ('must, have to'), a putea ('can, be able to') (used as impersonal verbs):
a. Rusia are de ne
plătit daune
Russia has DE $\mathrm{DE}_{\mathrm{SUP}}$ CL.ACC.1PL pay.SUP compensation.PL

'Russia has to pay compensations to us' (historia.ro)

b. Avem de ne plätit impozitele

have.PRES.1PL DE SUP CL.ACC.1PL pay.SUP tax.PL

'We have to pay our taxes' (www.bistriteanul.ro)

$\begin{array}{llllll}\text { c. mai aveți } & d e & \hat{\boldsymbol{i}} & \text { adus } & \text { pe } & \text { mama } \\ \text { still have.PRES.2PL } & \text { DE }_{\text {SUP }} & \text { CL.ACC.3PL } & \text { bring.SUP } & \text { DOM } & \text { mother }\end{array}$

şi tata lui Liliana

and father LUI.GEN Liliana

'You still need to bring Liliana's mother and father' (ziarulnational.md)

(27) a. Trebuie de le fácut observație urgent must DE $\mathrm{DE}_{\mathrm{SU}}$ CL.ACC.3PL make.PPLE observation urgently 'One must urgently let them know' (inprofunzime.md)

b. trebuie de le lăsat poarta deschisă spre plecare must DE $\mathrm{DE}_{\mathrm{SU}}$ CL.ACC.3PL leave.PPLE door open for leaving 'one must let the door open for them to leave' (m.publica.md)

c. Trebuie identificat persoane influente și de must identify.SUP/PPLE persons influent.PL and $\mathrm{DE}_{\text {SUP }}$ le convins să vină în board CL.ACC.3PL convince.SUP SĂ $\breve{S U B J}_{\text {SU }}$ come in board 'One must identify influential persons and make them join the board' (www.civic.md) 
a. cîte argumente se how.many arguments le adus contra lu Ghimpu CL.ACC.3PL bring.SUP against LUI.GEN Ghimpu 'how many arguments can one bring against Ghimpu?' (www.publika.md)

b. se poate de le aruncat CL.REFL.IMPERS can DE SUP $_{\text {S }}$ CL.ACC.3PL throw.away.SUP 'one can throw them away' (www.publika.md)

(ii) after aspectual verbs such as a se apuca de ('start'), a termina ('finish'), a se opri ('stop'):

(29)

a. mă CL.REFL.1SG think.PRES.1SG S $\breve{A}_{\text {SUBJ }}$ CL.REFL.1SG start.PRES.1SG de le citit $\mathrm{DE}_{\text {SUP }}$ CL.ACC.3PL read.sUP

'I am thinking of starting reading these' (jurnalul-unei-cititoare.blogspot.com)

b. dupăce termini de le arătat camerele after.what finish.PRES.2SG DE $\mathrm{EUP}_{\mathrm{SUP}}$ CL.ACC.3PL show.SUP rOoms.DEF.ACC 'after you finish showing them the rooms' (hd.portaltv.ro)

c. $\mathrm{nu}$ m-am oprit de le luat not CL.REFL.1SG=AUX.PERF.1SG stop.PPLE DE SUP $_{\text {SL.ACC.3PL take.SUP }}$ 'I did not stop taking them' (www.naturaplant.ro)

(iii) after conative verbs such as a încerca ('try'):

\begin{tabular}{llll} 
ca aceste răspunsuri & să & merite \\
that these answers & \multicolumn{1}{c}{$\breve{A}_{\text {SUBJ }}$} & worth.SUBJ.3PL \\
de incercat $d e \quad l e$ & căutat \\
$\mathrm{DE}_{\text {SUP }}$ try.SUP $\mathrm{DE}_{\mathrm{SUP}}$ & $\mathrm{CL} . \mathrm{ACC} .3 \mathrm{PL}$ & look.for.SUP \\
'in order for these answers to be worth looking for' (www.opinii.md)
\end{tabular}

(iv) after e greu de (i.e. 'tough-constructions'):

a. eu cred că aestea mici e mai greu

I believe that these little is more tough de le făcut $\mathrm{DE}_{\text {SUP }}$ CL.ACC.3PL make.PPLE

'I think that these little ones are tougher to make' (www.torrentsmd.com)

b. bune sfaturi, greu de le urmat good advice.PL tough $\mathrm{DE}_{\mathrm{SUP}}$ CL.ACC.3PL follow.SUP 'good advice, tough to follow' (blogs.fanbox.com)

(v) after adjectives taking complements introduced by de:

(32) $\begin{array}{llll}\text { demne } & d e & \boldsymbol{l} e & \text { urmat } \\ \text { worthy.F.PL } & \mathrm{DE}_{\mathrm{SUP}} & \text { CL.ACC.3PL } & \text { follow.SUP } \\ \text { 'worthy of following them' (ro-ro.facebook.com) }\end{array}$

(vi) in topic predicate fronting constructions:

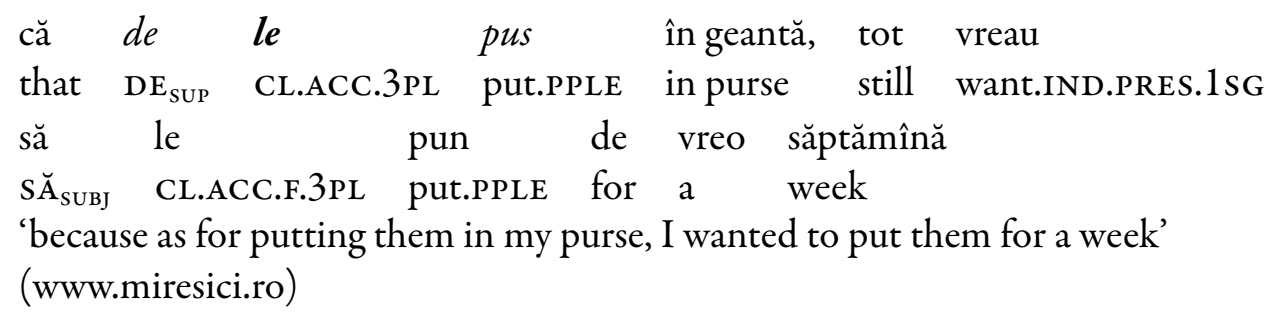


These examples also bear witness to another important feature of the supine in the varieties under investigation, namely the extension of its distribution in contrast to Standard Romanian. The supine may be selected by the modal verb a putea ('can, be able to') (used impersonally) and by the conative verb a incerca ('to try'). Furthermore, the modal verb a trebui ('must, have to') always selects a de-supine, in contrast to the standard language, in which trebui selects a bare supine (this representing the only context in which the verbal supine is not introduced by de) or a participle (see, for details, Sandfeld \& Olsen, 1936, p. 281; Rosetti, 1968, p. 258; Lombard, 1974, p. 301; Neamțu, 1980, p. 512-513; Pană Dindelegan, 2007 , p. 170-171,2011, p. 121; Dragomirescu, 2013a, p. 36-38, 2015).

\subsection{Combination with verbal negation}

While the Standard Romanian supine combines only with the prefixal negator ne-, but not with the freestanding negator $n u$ (see also Cornilescu \& Cosma, 2010 for a different interpretation of prefixal supine negation), in the north-eastern varieties the supine is compatible with the freestanding negator $n u$ :
a. Sîntmulte de spus, multe de nu le are many $\mathrm{DE}_{\mathrm{SUP}}$ say.SUP many $\mathrm{DE}_{\mathrm{SUP}}$ not CL.ACC.3PL say.SUP 'There are many things to be said and many things not to be said' (sorinels.blogspot.ro)
b. trebuia de nu le pus pampers need.IMPERF.3SG DE $\mathrm{DEU}_{\mathrm{SU}}$ not CL.ACC.3PL put.PPLE pampers 'It was necessary for us not to put them in pampers' (hainutebebe.com)

\subsection{Combination with clitic adverbs}

In contrast to the standard variety, in the dialects analysed the supine may combine with aspectual clitic adverbs:

$$
\begin{aligned}
& \text { Așa că trebuie de le lăsat poarta deschisă } \\
& \text { so that must } \mathrm{DE}_{\mathrm{SUP}} \text { CL.ACC.3PL leave.SUP door open } \\
& \text { spre plecare și de nu-i mai netezit pe bășcălie } \\
& \text { for leaving and } \mathrm{DE}_{\mathrm{SUP}} \text { not }=\mathrm{CL} . \mathrm{ACC} .3 \mathrm{PL} \text { more protect.SUP on mockingly }
\end{aligned}
$$

'One must leave the gate open for them to leave and not to mockingly protect them anymore' (m.publica.md)

\subsection{The agreeing supine}

Although in Standard Romanian the supine does not display agreement in any context, in the analysed varieties after the verb a trebui ('must, have to') the supine displays gender and number agreement with $3^{\text {rd }}$ person subjects (the $1^{\text {st }}$ and $2^{\text {nd }}$ person subjects are excluded from the agreeing configurations), irrespective of the position of the subject, i.e. raised to the main clause $(36 a-b)$ or in post-supine position (36c-e); gender and number agreement is also attested in tough-constructions (37).

a. $[\text { situația }]_{\mathrm{F} . S \mathrm{G}}$ trebuie de analizat $\breve{\mathrm{a}}_{\mathrm{F} . \mathrm{GG}}$ situation must $\mathrm{DE}_{\mathrm{SUP}}$ analyse.SUP.F.SG 'the situation must be analysed' (www.dejure.md)

b. Totuşi, [orice întrebare, temere, propunere $]_{\mathrm{F} . \mathrm{SG}}$ anyway any question fear proposal trebuie de discutatä $\breve{\mathrm{F}} . \mathrm{SG}_{\mathrm{Pu}} \mathrm{cu}$ medicul must DE SUP $_{\text {Sur }}$ discuss.SUP.F.SG with physician.DEF.ACC 'Anyway, any question, fear, proposal must be discussed with your physician' (odoras.com)

c. că trebuie de rezolvată $\breve{\mathrm{F} . S \mathrm{G}}$ [această problemă $]_{\mathrm{F} . S \mathrm{G}}$ that must $\mathrm{DE}_{\mathrm{SUP}}$ solve.SUP.F.SG this problem 'that this problem must be solved' (protv.md) 
d. trebuie de facută $\breve{\mathrm{F} . S G} \quad\left[\begin{array}{lll}\mathrm{o} & \text { cosmetică } & \text { ușoară }\end{array}\right]_{\mathrm{F} . S \mathrm{G}}$ must $\mathrm{DE}_{\mathrm{SUP}}$ make.SUP.F.SG a cosmetics light.F.SG 'one must make a light cosmetics operation' (999.md)

e. trebuie de făcute $e_{\mathrm{FPL}}$ și cîteva [observaţii critice $]_{\text {F.PL }}$ must DE $\mathrm{DE}_{\mathrm{SUP}}$ make.SUP.F.PL also a.few observations critical 'one must also make a few critical observations' (books.google.md)

$\begin{array}{llll}\text { are o muncă } & {[\mathrm{grea}]_{\mathrm{F} . \mathrm{SG}}} & \text { de } & \text { făcut } \breve{\mathrm{a}}_{\mathrm{FG}} \\ \text { has a job hard.F.SG } & \mathrm{DE}_{\mathrm{SUP}} & \text { make.F.SG } \\ \text { 'He has a hard job' (gandul.md) }\end{array}$

\subsection{Results and problems}

As we have seen in this section, the supine of the north-eastern varieties fundamentally contrasts with the Standard Romanian supine on the following points: (i) the extension of its distribution, (ii) its compatibility with pronominal clitics, the verbal negator $n u$ and the aspectual clitic adverb mai, and (iii) gender and number agreement. In the next section, we set the evolution of the Romanian supine against the evolution of the inflected infinitive in other languages, and we put forward a formal analysis which accounts for the present-day behaviour of the supine in the north-eastern varieties of Romanian.

\section{Analysis}

In the analysis that follows, we adopt the currently accepted generative clausal structure, according to which clausal structure is split into three layers: the CP-layer (the functional domain of the complementizer, which accommodates complementizers, wh-phrases and other elements displaced to the left periphery), the IP-layer (the functional domain which hosts mood-tense-aspect projections and the pronominal clitic field; the projection of this domain is also responsible for nominative assignment), and the $v$ P-layer (the lexical domain, where the verb and the core arguments are merged). Internal arguments are merged and case-marked in the lexical domain. By contrast, the external argument (the subject), although generated in the lexical domain (Koopman \& Sportiche, 1991), is dependent on the projection of the TP phrase (included in the IP-domain) for nominative assignment (Chomsky, 1981; see Cornilescu, 2000 and Stan, 2005 for Romanian).

\subsection{Standard Romanian supine}

The syntactic diagnostics reviewed above (absence of subject, incompatibility with verbal negation, pronominal clitics and clitic adverbs) indicate that the supine has a reduced functional structure-cf. many proposals about structure of imperatives in many languages-, as proposed in (38):

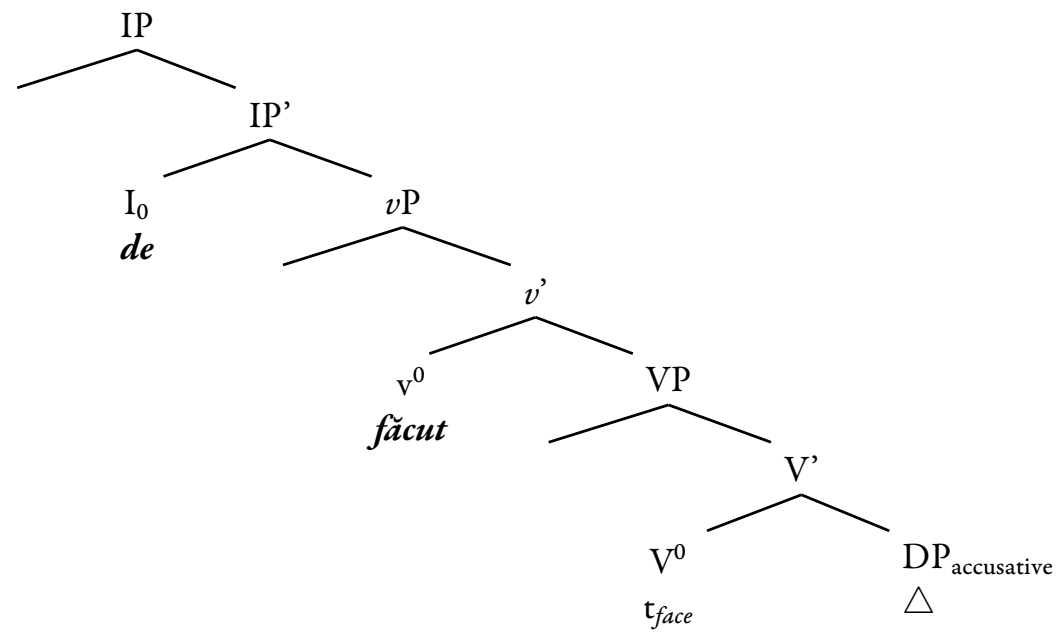


According to this representation, in the functional structure of the supine the C-domain is not projected at all, and the I-domain (which, in Romanian, accommodates the negation phrase, the clitic-hosting person phrases, and the mood, tense, and aspect phrases ordered as such-see, for details, Nicolae, 2015) is defective: the NegP, the TP (responsible for nominative assignment) and the pronominal-clitic-hosting PersP are absent, the entire I-domain of the supine being occupied by the marker $d e$. By contrast, the lexical domain $v$ P is fully projected, as shown by the fact that the supine may take accusative direct objects (generated as sisters to V) and dative indirect objects ( $S$-a apucat [de trimis cadouri copiilor dative $_{\text {supine }}$ 'He started sending gifts to the children'); indirect objects are also generated in the $v \mathrm{P}$-domain, as specifiers of an Applicative phrase (ApplP) (i.e. $v>A p p l$ ). The absence of the subject in (non-raising) supine configurations follows from the absence of the TP-projection in the functional structure of the supine: without a TP-projection, nominative assignment is not available, and the existence of a caseless nominal violates The Case Filter (Chomsky, 1981).

\subsection{Dialectal supine}

In contrast to the Standard Romanian supine, the dialectal supine has developed a richer functional structure, as shown in (39):

(39)

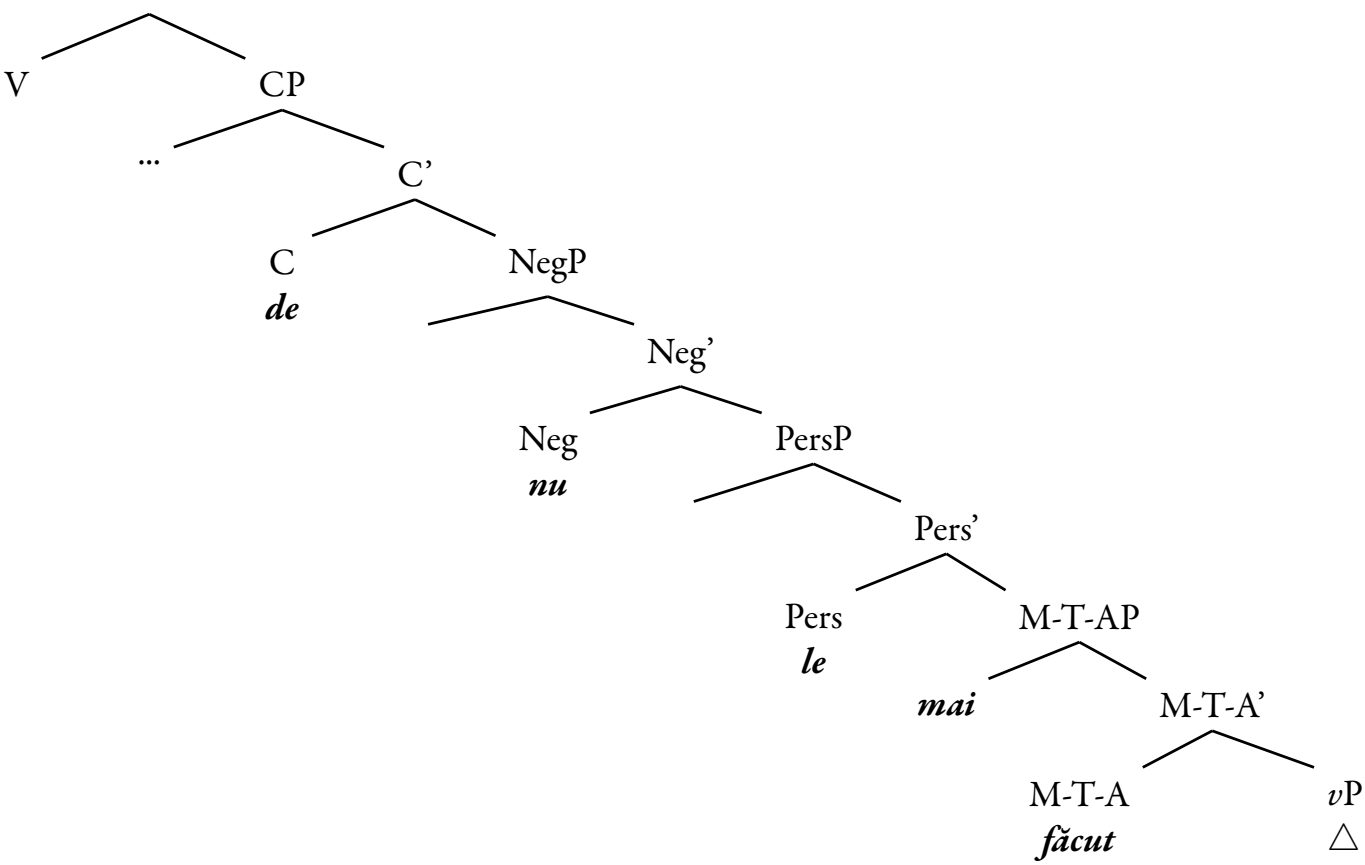

The functional structure of this supine is thus more similar to that of the finite clause, in which all functional layers, CP, IP and $v \mathrm{P}$, are projected. The marker de has been pushed upwards in the structure, becoming a C-head; thus, in these varieties, we witness the reanalysis of this inflectional element as a complementizer. Furthermore, it appears that the C-domain has developed a left periphery which may accommodate focused and topicalized constituents (40) (Hill \& Dragomirescu, 2014). However, these examples are ambiguous, because the boldfaced constituents can be also interpreted as modifying the main verb.

$$
\begin{aligned}
& \text { a. și trebuie [cumva de le adus] } \\
& \text { and must somehow } \mathrm{DE}_{\mathrm{SUP}} \text { CL.ACC.3PL bring.SUP } \\
& \text { ca nimeni să nu știe } \\
& \text { that nobody } \breve{S}_{\text {SUBJ }} \text { not know.sUBJ.3sG } \\
& \text { 'and one must bring them somehow, in order for no one to know' (unimedia.info) }
\end{aligned}
$$



b. Trebuie $\left[\begin{array}{llll}\boldsymbol{l a} & \boldsymbol{b o t} & \mathrm{de} & \mathrm{dat}\end{array}\right]$
must at mouth $\mathrm{DE}_{\mathrm{Sup}}$ give.PPLE
'One must hit them in the mouth' (www.timpul.md)

The I-domain is richer than in the standard language, accommodating at least the following phrases (specific to finite clauses with a fully articulated functional domain): the NegP, which hosts the clausal negator, the PersP (/Person-field), which accommodates pronominal clitics, and the AspP (/an Asp-field, à la Cinque, 1999), responsible for the merger of aspectual clitic adverbs. In the data examined so far, we have not encountered supines with their own nominative subject distinct from the subject of their selecting verb; thus, there is no significant empirical evidence for a nominative-assigning TP. In conclusion, while the functional structure of the dialectal supine is obviously richer, it is, however, impoverished in certain respects when compared to the structure of fully articulated finite clauses.

The full CP-status of the dialectal supine is further confirmed by the fact that it may undergo CPtopicalization:

$$
\begin{aligned}
& \text { a. dar }\left[\begin{array}{lll}
d e & l e & a d u s
\end{array}\right]_{\mathrm{i}} \text { trebuie } \mathrm{t}_{\mathrm{i}} \\
& \text { but } \text { DE }_{\text {SUP }} \text { CL.ACC.F.3PL bring.PPLE must } \\
& \text { 'but bring them, one must' (www.realizat.com) } \\
& \text { b. }\left[\begin{array}{llll}
D e & l e & \text { scris }
\end{array}\right]_{\mathrm{i}} \text { nu e greu } \mathrm{t}_{\mathrm{i}} \text {, } \\
& \mathrm{DE}_{\text {SUP }} \text { CL.ACC.F.3PL write.PPLE not is hard } \\
& \text { am adăugat una } \\
& \text { AUX.PERF.1SG write.PPLE one } \\
& \text { 'writing them isn't hard, I added one' (forum.softpedia.com) }
\end{aligned}
$$

\subsection{The supine on the finiteness scale}

The analysis of the dialectal supine from the perspective of the finiteness scale (24) put forward by Ledgeway (1998 and ssq.) indicates that this form behaves exactly like the Romance inflected infinitive, in that it displays all the features of a finite clause, except for the ability to take its own lexical subject. Consequently, the dialectal supine is characterized as [- Tense, + Agreement], which indicates that its Idomain, although featuring at least a NegP, a PersP (/Person-field), an AspP (/Asp-field), is still defective, i.e. its nominative-assigning TP is absent. In other words, the dialectal supine is morphologically finite (i.e., it displays morphological agreement), but syntactically non-finite (i.e., it is unable assign nominative case) (see Ledgeway, 2007).

\section{Conclusions}

This paper has examined the behaviour of the inflected supine attested in the north-eastern varieties of Romanian against the behaviour of the inflected infinitive attested in various Romance and non-Romance languages.

The analysis presented above allows us to formulate a few conclusions which concern, on the one hand, the category of 'finiteness' and its diachronic behaviour, and, on the other hand, the diachronic changes affecting the Romanian supine.

(i) Owing to its array of heterogeneous morphological, syntactic and semantic features, 'finiteness' is one of the least understood linguistic concepts (Ledgeway, 2007). Furthermore, the diachronic changes affecting it are also incongruous. For example, in the passage form Old to Modern Neapolitan, the inflected infinitive has been replaced by the personal and canonical infinitives, while the Romanian supine, which has been morphologically invariable and had a reduced functional structure, has become an inflected 'non-finite' form with an enriched functional structure in the dialects examined. Thus, diachronically, the degree of finiteness of a certain verbal form may become enriched or impoverished. 
Furthermore, it is clear that the label 'infinitive' covers forms with a different internal structure in different languages.

(ii) As stressed in Section 2.4, the idea that the Romance inflected infinitive does not originate from the canonical infinitive, but rather from finite forms (subjunctive, indicative) is largely accepted. The inflected infinitive emerges from the canonical infinitive in non-Romance languages (Romeyka, Hungarian). From this perspective, Romanian is drawn closer to the non-Romance languages discussed here by its dialectal inflected supine, which emerged from the canonical supine.

(iii) However, from the perspective of the diachrony of non-finite forms, there are however similarities between Romanian and other Romance languages. Consider the Portuguese canonical infinitive: in Old Portuguese, this form was not compatible with pronominal clitics and clausal negation (which underwent raising to the higher predicate), while the Modern Portuguese inflected infinitive is compatible with both negation and pronominal clitics. The Romanian supine is undergoing a similar path of diachronic change, as synthesized in (iv) below.

(iv) The diachrony of the Romanian supine obviously involves an enrichment of the functional structure: projections like Negation, Person, and Aspect which are absent in the functional structure of the Standard Romanian supine become available in the north-eastern varieties. Agreement in contexts in which the supine is selected by the verb a trebui ('must, have to') or in tough-constructions, albeit poorly attested, indicates that acquisition of a full set of $p h i$-features by the supine is well underway. Gender agreement makes the Romanian supine different from other non-finite forms in the Romance languages which show person and number agreement. The diachrony of the Romanian supine thus indicates that one possible path of syntactic change is enrichment of functional structure. This conclusion is somewhat surprising judging from what we know about syntactic change: traditional wisdom insists on the diachronic reduction of syntactic structures (cf., for example, Harris \& Campbell, 1995, Chapter 7, Processes that simplify biclausal structures); the diachrony of the inflected non-finite forms illustrates the very opposite situation: enrichment of syntactic structure.

(v) The supine marker de has an interesting diachronic path. At the point at which the ambiguous (verbalnominal) supine grammaticalizes as a verbal supine, the preposition de is reanalysed as an inflectional head (Dragomirescu, 2013a,b), following a familiar path of grammaticalization, identified, for example, in the grammaticalization of the Dutch te-infinitive (Ijbema, 2002). The enrichment of the functional structure of the supine in the dialects triggers the reanalysis of the inflectional marker de as a complementizer: in other words, from the perspective of the representations in (38) and (39), the marker de an I-element in Standard Romanian, is "pushed up" and reanalysed as a C-head in the dialects. This path of diachronic change (inflectional marker > complementizer) is in agreement with the theory of syntactic change put forward by Roberts \& Roussou (2003), according to which grammaticalization involves movement and subsequent reanalysis to the left, i.e. in a hierarchically higher position.

\section{Acknowledgements}

We would like to express our gratitude to the following colleagues who read our paper or discussed with us various problems addressed here: Adam Ledgeway, Martin Maiden, Gabriela Pană Dindelegan, and David Pesetsky. The first draft of the paper was presented at the MIT LingLunch on April 7, 2016; we are grateful to the MIT colleagues for their comments and suggestions.

\section{Bibliography}

Bentley, D. (2014). On the personal infinitive in Sicilian, in: P. Benincà, A. Ledgeway, N. Vincent (eds), Diachrony and Dialects. Grammatical Change in the Dialects of Italy, Oxford University Press, Oxford, p. 96-115, Crossref.

Bossaglia, G. (2013). Inflected/Non-inflected Infinitive Alternation in Causative and Perception Constructions of Contemporary European Portuguese: A Corpus-based study, in "Procedia - Social and Behavioral Sciences", vol. 95, p. 220-230, Crossref. 
Carvalho, M.J. (2015). Para a história do infinitive flexionado português: uma abordagen semântico-pragmática, in "Zeitschrift für romanische Philologie", vol. 311, no. 3, p. 664-689, Crossref.

Chomsky, N. (1981). Lectures on Government and Binding, Foris, Dordrecht.

Cinque, G. (1999). Adverbs and Functional Heads: A Cross-Linguistic Perspective, Oxford University Press, Oxford.

Cornilescu, A. (2000). The double subject construction in Romanian, în: V. Motapanyane (ed.), Comparative Studies in Romanian Syntax, Elsevier, Amsterdam / Lausanne / New York / Oxford / Shannon / Singapore / Tokyo, p. 83-133.

Cornilescu, A. \& Cosma, R. (2010). Remarks on the Romanian Verbal Supine and its German Equivalents, talk given at The Annual Conference of the Faculty of Foreign Languages and Literatures, Universitatea din București, November 5-6.

Dragomirescu, A. (2011). The subject of the supine clause in Romanian and A-chains, in "Revue roumaine de linguistique", vol. LXI, no. 4, p. 371-392.

Dragomirescu, A. (2013a). Particularități sintactice ale limbii române în context romanic. Supinul, Editura Muzeului Național al Literaturii Române, București.

Dragomirescu, A. (2013b). Du latin au roumain. Une nouvelle hypothèse sur l'origine du supin en roumain, in "Revue de linguistique romane", vol. 77, no. 305-306, p. 51-85.

Dragomirescu, A. (2015). Utilizări dialectale ale supinului, in: R. Zafiu, I. Nedelcu (eds.), Variația lingvistică: probleme actuale. Actele celui de al 14-lea Colocviu al Departamentului de Lingvistică, I, Editura Universității din București, București, p. 3948.

Dragomirescu, A. \& Hill, V. (2014). A diachronic perspective on de-supine complements, talk given at ACED, Universitatea din București, June 5-7.

Gabinschi, M. (2010). Formele verbale nepredicative nonconjunctivale ale limbii române (pe marginea tratării lor în gramatica oficială), Chișinău.

Gamillscheg, E. (1970). Studien zur Vorgeschichte einer romanischen Tempuslehre (= Sitzungsberichte der Kais. Akademie der Wissenschaften in Wien, Phil.-hist. Kl., 172. Bd., 6. Abhandlung.), Tubinger Beitrage zur Linguistik, Tubingen; $1^{\text {st }}$ ed.: 1913.

Groothuis, K. (2015). The inflected infinitive in Romance, talk given at the workshop Romance Syntax. Comparative and Diachronic Perspectives, Universitatea din București, November 27-28.

Harris, A. \& Campbell, L. (1995). Historical Syntax in Cross-Linguistic Perspective, Cambridge University Press, Cambridge, Crossref.

Hill, V. \& Dragomirescu. A. (2014). De-supine complements in Romanian: a paradigmatic view, talk given at LSRL 44, May 2-4.

Ijbema, A. (2002). Grammaticalization and infinitival complements in Dutch, LOT Publications, Utrecht, [online].

Jones, M. A. (1992). Infinitives with specified subjects in Sardinian, in: C. L Laeufer, T. A. Morgan (eds), Theoretical analyses in Romance linguistics, John Benjamins, Amsterdam, p. 295-309, Crossref.

Jones, M. A. (1993). Sardinian syntax, Routledge, London.

Jones, M. A. (2003). Sintassi della lingua sarda: Sardinian syntax (R. Bolognesi, Trans.), Condaghes, Cagliari.

Kiss, K. (1987). Configurationality in Hungarian, Reidel, Dordrecht - Boston, Crossref.

Koopman, H. \& Sportiche, D. (1991). The Position of Subjects, in "Lingua", vol. 85, no. 2-3, p. 211-258, Crossref.

Ledgeway, A. (1998). Variation in the Romance infinitive: the case of the Southern Calabrian inflected infinitive, in "Transactions of the Philological Society", vol. 96, no. 1, p. 1-61, Crossref.

Ledgeway, A. (2000). A Comparative Syntax of the Dialects of Southern Italy: A Minimalist Approach, Wiley-Blackwell, Oxford.

Ledgeway, A. (2007). Diachrony and Finiteness: Subordination in the Dialects of Southern Italy, in: I. Nikolaeva (ed.), Finiteness: Theoretical and Empirical Foundations, Oxford University Press, Oxford, p. 335-365.

Ledgeway, A. (2009). Grammatica diacronica del napoletano, Niemeyer, Tübingen.

Lombard, A. (1974). La langue roumaine. Une présentation, Éditions Klincksieck, Paris.

Loporcaro, M. (1986). L'infinito coniugato nell'Italia centro-meridionale: ipotesi genetica e ricostruzione storica, in "Italia dialettale", vol. 49, p. 173-140.

Madeira, A.-M. (1994). On the Portuguese Inflected Infinitive, in “UCL Working Papers in Linguistics”, 6, p. 179-203.

Martins, A.M. (2006). Aspects of infinitival constructions in the history of Portuguese, in: R. Gess, D. Arteaga (eds), Historical Romance Linguistics: Retrospective and perspective, John Benjamins, Amsterdam, p. 327-355, Crossref.

Maurer, T.H., Jr. (1984). O Infinito Flexionado Portugues: Estudo historico-descritivo, Editora Nacional, Sao Paulo; $1^{\text {st }}$ ed.: 1968.

Mensching, G. (2000). Infinitive Constructions with Specified Subjects. A Syntactic Analysis of the Romance Languages, Oxford University Press, Oxford.

Miller, D. G. (2003). Where do conjugated infinitives come from, in "Diachronica”, vol. 20, no. 1, p. 45-81, Crossref.

Miller, D.G. (2004). The origin of the Welsh conjugated infinitive, in "Diachronica”, vol. 21, no. 2, p. 329-350, Crossref.

Neamțu, G. G. (1980). Despre construcția „a trebui + participiu”, in “Limba română”, vol. XXIX, no. 5, p. 511-514.

Nedjalkov, I.V. (1995). Converbs in Evenki, în: M. Haspelmath, E. Konig (eds), Converbs in Cross-Linguistic Perspective. Structure and meaning of adverbial verb forms-adverbial participles, gerunds, Mouton de Gruyter, Berlin - New York, p. 441-463.

Nedjalkov, I. V. (1997). Evenki, Routledge, London - New York. 
Nicolae, A. (2015). Ordinea constituenților în limba română: o perspectivă diacronică. Structura propoziţiei și deplasarea verbului, Editura Universității din București, București.

Pană Dindelegan, G. (2007). Din nou despre participiu şi supin, in "Studii şi cercetări lingvistice”, vol. LVIII, no. 1, p. $163-173$.

Pană Dindelegan, G. (2008). Supinul, în: V. Guțu Romalo (ed.), Gramatica limbii române, I. Cuvântul, Editura Academiei Române, București, p. 509-524.

Pană Dindelegan, G. (2011). Din istoria supinului românesc, in: R. Zafiu, C. Uşurelu, H. Bogdan Oprea (eds.), Limba română - ipostaze ale variației lingvistice, I, Editura Universităţii din Bucureşti, Bucureşti, p. 119-130.

Pană Dindelegan, G. (2013). The supine, in: G. Pană Dindelegan (ed.), The Grammar of Romanian, Oxford University Press, Oxford, p. 233-245.

Pires, A. (2002). Cue-Based Change: Inflection and Subjects in the History of Portuguese Infinitives, in: D. Lighfoot (ed.), Syntactic Effects on Morphological Changes, Oxford University Press, Oxford, p. 143-159, Crossref.

Raposo, E. (1987). Case Theory and Infl-to-Comp: The Inflected Infinitive in European Portuguese, in "Linguistic Inquiry", vol. 18 , no. 1, p. 85-109.

Rizzi, L. (1978). A restructuring rule in Italian syntax, in: S. J. Keyser (ed.), Recent Transformational Studies in European Languages, MIT Press, Cambridge, MA, p. 113-158.

Roberts, I. \& Roussou, A. (2003). Syntactic Change. A Minimalist Approach to Grammaticalization, Cambridge University Press, Cambridge.

Roberts, K.S. (ed.) (1953-1957). An Anthology of Old Portuguese, Livraria Portugal, Lisbon.

Rodrigues, J. M. (1913). O imperfeito do conjuntivo e o infinitivo pessoal no Portugues, in "Academia das Sciencias de Lisboa: Boletim da Segunda Classe", 8, p. 72-93.

Rosetti, Al. (1968). Istoria limbii române de la origini pînă în secolul al XVII-lea, Editura pentru Literatură, Bucureşti.

Rouveret, A. (1980). Sur la notion de proposition finie. Gouvernement et inversion, in "Langages", vol. 14, no. 60, p. 75-107, [online].

Sandfeld, Kr. \& Olsen, H. (1936). Syntaxe roumaine. Emploi des mots á flexion, I, E. Droz, Paris.

Scida, E. (2004). The inflected infinitive in Romance languages, Routledge, New York - London.

Sheehan, M. (2015). Control of Inflected Infinitive in European Portuguese, ms, [online].

Sitaridou, I. (2014). The Romeyka infinitive. Continuity, contact and change in the Hellenic varieties of Pontus, in "Diachronica", vol. 31, no. 1, p. 23-73, Crossref.

Stan, C. (2005). Categoria cazului, Editura Universităţii din București, București.

Tallerman, M. (1998). The Uniform Case-licensing of Subjects in Welsh, in “The Linguistic Review”, vol. 15, no. 1, p. 69-133.

Taylor, C. (2016). Aspects of Clause Structure in Nicoterese. A Descriptive Account, PhD dissertation, University of Cambridge. Terzi, A. (1997). PRO and Null Case in Finite Clauses, in "The Linguistic Review”, vol. 14, no. 4, p. 335-360.

Vincent, N., (1998). On the grammar of inflected non-finite forms (with special reference to Old Neapolian), in: L. Korzen, M. Herslun (eds), Clause combining and text structure, Samfundlitteretur, Copenhagen, p. 135-158.

Willis, C. (1971). An essential course in Modern Portuguese (Revised edition), Nelson, Hong Kong. 